Committee. Essentially, the work of the Joint Committee will be divided into two fields of activity, national and international, of which the former will no doubt be of major importance. As a commencement in this field, the Committee is now engaged in making arrangements for a general discussion on the subject of the notched bar test to be held in Manchester in the early autumn of the present year. The activities of the International Association for Testing Materials in Great Britain are at present entrusted to the keeping of a British Committee, and the latter has agreed that, at the conclusion of the London Congress of the International Association for Testing Materials now being held (April 19-24), the Joint Committee shall take over the representation in Great Britain of all matters connected with the International Association. The first chairman of the Committee is Dr. H. J. Gough, largely through whose initiative the Joint Committee has come into being; the secretary is Mr. C. W. J. Taffs, of the staff of the Institution of Mechanical Engineers, the Council of which has kindly offered the necessary facilities for office work at Storey's Gate, St. James's Park, London, S.W.1.

\section{New Commonwealth Society}

THE fourth annual report of the New Commonwealth Society and Institute for the year ended September 30, 1936, refers to the way in which the events of the year have emphasized the soundness of the thesis of an equity tribunal and an international police force which the Society was created to advocate, and the report indicates that the New Commonwealth Society is rapidly gaining ground. Forty-four countries are now represented in the membership, which including the international members shows an effective increase of 252 on the year. The position of the group associate membership is less satisfactory. In addition to the publication of the journal and numerous pamphlets during the year, the British Section has initiated a scheme for a "Writers Panel" to develop publicity in the Press. Brief reviews of the activities of other national sections are included in the report. The section dealing with the New Commonwealth Institute outlines the progress of collective research on procedure for peaceful change, a basis for which has been provided by a report prepared by Prof. K. Strupp dealing with the possibility of an international peace convention and peace charter. A department for collective research on the organization of some form of international force has been initiated under Capt. E. Abraham, and similar activity has also been initiated on the reform of the League of Nations. Detailed proposals have already been forwarded to the members of the Advisory Research Committee and to the Foreign Offices of all States members of the League. A further development in the year is the organization of an information department.

\section{Additional Food for the Special Areas}

A MEMORANDUM on the Special Areas Bill dealing with the provision for additional food, etc., for mothers and children in distressed areas has been submitted to the Prime Minister by the Children's Minimum Council. The memorandum submits evidence of the inadequacy of incomes in distressed areas based, in respect of food, on figures given in "A Revised Estimate of the Poverty Line" by R. F. George (J. Roy. Statistical Soc.). The figures indicate broadly the increasing extent to which the incomes of the unemployed fall below the requirements for health as the size of the family increases. Other evidence of the lack of nourishment of mothers and children in these areas is presented, and the limitations of the present provision by local authorities in England and Wales in consequence of the inability of local rates to support it are also reviewed and discussed. The memorandum urges that the Government should provide in the fortheoming Bill for grants from the national exchequer to local authorities in the Special Areas to cover the whole cost of the supply of free milk to all children in public elementary schools and to scholarship children in secondary schools; the supply of free school meals to all children belonging to families where the amount available for food falls below a scale to be determined by the Ministry of Health; the supply of free boots to school children in such families; and the supply of free milk to expectant and nursing mothers and to children under school age in such families.

\section{Lancashire and Cheshire Fauna}

THe twenty-second report of the Lancashire and Cheshire Fauna Committee, just issued, which covers 1935 , is probably the most useful publication of the Committee apart from its Check List. It deals chiefly with vertebrates, and in addition to the records of the occurrence of rare species, includes detailed tables of the distribution of the woodcock, grey squirrel and great crested grebe in Cheshire, and the pochard, great spotted woodpecker and redstart in both counties. The committee which announces it is also to include the recording of the marine fauna within the three mile-limit in its work, makes an addition of 101 species new to both counties and 25 new to one county, the former consisting of 28 Coleoptera, 20 Diptera, 20 Hymenoptera, 12 sawflies, 8 Acari, 5 Hemiptera, 2 Mallophaga and Neuroptera and I each of Mollusca, Lepidoptera, Anoplura and Siphonaptera. The more interesting specific records are: a new colony of Natterjack toads at Storeton, Cheshire; a November golden oriole at Macclesfield; numerous reports of the invasion of crossbills ; a meadow-pipit at Heywood, Lancashire, with an abnormal clutch of five sky blue eggs spotted with red, and a magpie that has developed the habit of nesting on the ledge of a steep moorland cliff there ; a chiffchaff wintering there, although it does not nest in the district; a December immigration of blackbirds ; an investigation of swallow broods showing that 35 broods in Lancashire averaged 4.05 young and 97 broods in Cheshire averaged 4 young; a kestrel taken in Manchester and found to have its plumage and its nostrils so heavily laden with soot that none of the usual parasites inhabited it. 